\title{
Urgensi Pemikiran Kritis dalam Pengembangan Kriminologi Indonesia di Masa Mendatang
}

\author{
M. Abdul Kholiq
}

\begin{abstract}
Crime is as social phenomena which is interesting to be discussed in order to overcome a comprehensive solution. The science of criminology is a significant study, which is especially aimed to examine the cause and effect of crime (etiology) and the criminal policy. There are three prominent theories which have been taken into consideration in the current of criminology development. These include Classics theory, Positive theory and Critical theory. All of these theories, the critical theory is the most comprehensive and valid approach in responding to formulate the essence of crime and criminals. For the future of Indonesian Criminology development, it is very significant to adopt the critical theory. This argument is supported by the fact that crime can not only be defined as such as law, but also needs a wider of understanding of social phenomena, cultural and constructed concept of government.
\end{abstract}

\section{Pendahuluan}

Hal pertama yang harus dikemukakan untuk menguraikan tema tulisan di atas ialah bahwa "memotret" secara tepat perkembangan pemikiran kriminologi di Indonesia bukanlah pekerjaan mudah. la memerlukan "penglihatan" yang cermat, mendalam serta bersifat kontinyu terhadap tulisan-tulisan para ahli yang memiliki kompetensi sebagai kriminolog. Dalam konteks Indonesia sampai sekarang ini belum ada suatu forum/wadah yang

representatif sebagai tempat menampung pemikiran-pemikiran kriminologis ala Indonesia. ${ }^{1}$

Menimbang realita di atas, maka paparan dalam tulisan ini tidak bisa tidak harus "mengambil" khasanah kepustakaan mengenai teori-teori kriminologi yang selama-ini telah dibentangkan oleh para ahlinya di dunia barat. Tentu saja agar supaya analisis dan hasil kesimpulannya tidak terlepas dari akar kriminologi Indonesia (sesuai dengan tema),

'Lahimya organisasi bernama ASPEHUKI (Asoșiasi Pengajar Hukum Pidana dan Kriminologi) di Indonesia selama.ini tampaknya belum mencerminkan suatu kinerja yang efektif. Sehingga belum sah kiranya untuk dijadikan referensi dalam melihat pemikiran-pemikiran kriminologis Indonesia. 
maka mutlak pula kiranya apabila kajiannya mesti "membuka" pemikiran kriminolog Indonesia sebagai mana tersebar dalam berbagai tulisan (buku).

Dalam rangka memahami hakekat aliran/ pemikiran kritis itu dan bagaimana pula urgensinya bagi pengembangan "sosok" kriminologi Indonesia pada masa mendatang, diperlukan telaah historis perkembangan pemikiran teoritik kriminologi pada umumnya. Lahirnya pemikiran kritis tentu bukan sesuatu yang tiba-tiba muncul begitu saja. Eksistensinya melalui suatu proses "benturan" argumentasi panjang dengan aliran-aliran/ pemikiran yang sebelumnya telah eksis terlebih dahulu dalam khasanah "rimba" ilmu kriminologi, seperti pemikiran klasik dan positivis.

Aliran kritis dalam kriminologi yang sering pula "kriminologi baru", "kriminologi radikal", "kriminologi sosialis", "kriminologi sayap kiri" atau bahkan sering. dituduh pula sebagai "kriminologi marxis", pernah menjadi tema diskusi panjang di kalángan ilmuwan sosial Indonesia.

Akademisi yang pro terhadap pemikiran kritis tersebut yang di antaranya diwakili oleh kriminolog muda Mulyana W. Kusuma, dalam berbagai forum maupun tulisan-tulisan yang tersebar sering beradu pikiran secara tajam dengan akademisi yang kontra yang antara lain diwakili oleh J. E. Sahetapy. ${ }^{2}$ Dalam sejarah, pada sekitar akhir 1970-an atau awal 1980-an disebabkan oleh karena label Marxis tersebut (suatu paham yang dalam konteks orde baru dianggap "haram" karena diidentikkan dengan komunis), pernah terjadi penguasa menerapkan suatu kebijakan yang "menyembelih" kebebasan-kebebasan akademik di kalangan ilmuwan yang dianggap terlalu kritis di dalam menganalisa fenomenafenomena sosial yang "pincang" sebagai akibat dari penerapan kebijakan publik oleh penguasa. $^{3}$

Realita kontroversialitas terhadap keberadaan pemikiran kritis di atas secara akademik tentu menarik untuk dikaji dalam rangka mencari jawab apakah sesungguhnya pemikiran tersebut dan bagaimana prospek serta urgensinya dalam konteks kriminologi Indonesia. Analisis terhadap persoalan di atas dimaksudkan agar "sosok" pemikiran kritis dapat ditempatkan dan disikapi secara proporsional dalam arti tidak didramatisir. Apalagi harus dicurigai secara negatif.

\section{Pemikiran Kritis sebagai Upaya Alternatif Pengembangan Kriminologi}

Dalam perspektif sejarah setidaknya sampai dengan tahun 1960-an, studi kriminologi masih ditekankan pada kajian tentang sebab musabab kejahatan (etiology criminal) dan pemberantasan/kontrol terhadap fenomena

${ }^{2}$ Lihat antara lain karya Sahetapy. 1992. Teori Kriminologi : Suatu Pengantar. Bandung: Penerbit PT Citra Aditya Bakti. HIm. 47-58.

${ }^{3}$ Lihat hasil wawancara dengan!.S. Susanto. Termuat dalam Buletin FOKUS. Edisi No. I/SPP/XVIDesember 1996. 
kejahatan tersebut (politik kriminal). ${ }^{4}$ Pada waktu itu kejahatan umumnya dipandang sebagai tindakan yang immoril dan merugikan masyarakat. Oleh karenanya, dengan sadar ditentang oleh negara. Perbuatan yang dimaksud dituangkan secara formal dalam aturan perundang-undangan hukum pidana sebagai perbuatan yang terlarang dan pembangkangan terhadap aturan perundangundangan tersebut diancam dengan reaksi formal yang tegas dalam bentuk pemberian penderitaan tertentu (sanksi pidana).

Pandangan tersebut di atas itulah yang dinamakan sebagai aliran/pemikiran klasik dalam kriminologi. Dalam perspektif aliran ini, kejahatan dan penjahat umumnya hanya dipandang dari sudut yuridis. Kejahatan adalah perbuatan yang dilarang oleh undangundang pidana, sedangkan penjahat adalah orang yang melakukan kejahatan menurut hukum pidana. Kejahatan dipandang sebagai hasil pilihan bebas (free will) dari individu yang menilai untung ruginya melakukan kejahatan. Tanggapan rasional yang diberikan oleh masyarakat adalah agar individu tidak melakukan pilihan dengan berbuat kejahatan yaitu dengan cara meningkatkan kerugian yang harus dibayar dan sebaliknya dengan menurunkan keuntungan yang dapat diperoleh dari melakukan kejahatan. Dalam hubungan ini, maka tugas kriminologi adalah membuat pola dan menguji sistem hukuman (pemidanaan) yang akan meminimalkan tindak kejahatan. ${ }^{5}$

Jadi, , menurut pandangan klasik ini, pemidanaan adalah suatu solusi/cara untuk menanggulangi kajahatan (control of crime) yang dapat dibenarkan dan sekaligus juga pembenaran untuk eksistensi hukum pidana dan sistem peradilan pidana.

Secara teoritis, latar belakang pemikiran ini dilandasi suatu asumsi bahwa hukum pidana yang mengatur tentang kejahatan itu hakekatnya adalah refleksi dari suatu konsensus/kesepakatan masyarakat mengenai perilaku atau perbuatan yang oleh masyarakat dirasakan sebagai hal paling merugikan dan oleh karenanya, maka tidak boleh dibiarkan. Menurut Romli, ${ }^{6}$ teori/model konsensus sebagai salah satu perspektif yang berfungsi untuk menjelaskan hubungan antara eksistensi hukum dan masyarakat (teori/model lainnya antara lain ialah model pluralis dan model konflik), dipengaruhi oleh postulatpostulat sebagai berikut: (1) masyarakat merupakan suatu struktur yang relatif stabil; (2) pada dasarnya masyarakat telah terintegrasi secara baik; (3) fungsi struktur sosial didasarkan pada kesepakatan atas nilainilai; (4) dalam konteks kelahiran hukum, dipandang hukum adalah merupakan cermin kehendak masyarakat banyak. Semua anggota masyarakat telah sepakat tentang apa yang benar dan apa yang tidak benar dan

"Henkie Liklikuwata. 1990.Sosiologi Hukum Pidana, Kejahatan dan Penjahat: Suatu Sketsa Jakarta: Penerbit IND HILL CO. HIm. 3.

I.S. Susanto. 1993. Kriminologi. Semarang: Bagian Penerbitan Fakultas Hukum Universitas Diponegoro. HIm. 13.

${ }^{6}$ Romli Atmasasmita. 1984. Bunga Rampai Kriminologi. Jakarta: CV. Rajawali. HIm. 89-90. 
hukum hanyalah semata-mata suatu bentuk pernyataan tertulis dari kesepekatan tersebut; (5) hukum melayani berbagai kepentingan dalam masyarakat secara adil/sama. Oleh karena ia menceminkan kehendak masyarakat banyak, maka ia tidak menekan atau melayani kepentingan hanya kepada salah satu dari kelompok-kelompok tadi; dan (6) para pelanggar hukum hakekatnya adalah mewakili suatu kelompok yang bersifat unik. Oleh karena sebagian besar masyarakat telah sepakat tentang apa yang benar dan apa yang tidak benar, kelompok kecil yang melanggar hukum tadi dipandang memiliki ciri-ciri tersendiri yang berbeda dengan kelompok terbesar yang taat pada hukum.

Apabila diperhatikan dengan seksama beberapa hal yang mendasari teori konsensus pemikiran klasik di atas, terlihat menggambarkan bahwa untuk konteks sekarang aliran pemikiran ini tampak penuh dengan idealita-idealita yang nyaris menjadi suatu utopia. Semua yang dijelaskan seolah mengisyaratkan bahwa realitas kehidupan sosial yang sangat kompleks dan heterogen ini tidak mencerminkan adanya persoalan karena mekanisme hukum diasumsikan telah sedemikain mantap bekerjanya. Tentu saja secara hakiki, dalam hubungan ini sangat sah kiranya apabila diajukan suatu "gugatan" mendasar berkaitan dengan realita yang sesungguhnya. Maksudnya bahwa dalam kenyataan, sepanjang sejarah kehidupan masyarakat manusia belumlah ada tercipta suatu realitas kehidupan sosial yang betulbetul stabil di mana individu-individunya sama sekali tidak memiliki perbedaan interest sehingga selalu dapat melahirkan kosensuskonsensus. Hal demikian ini mengingat bahwa pada hakekatnya tiap-tiap individu itu mempunyai karakteristik sikap dan perilaku sendiri-sendiri dalam merespon realitas yang ada di sekitar kehidupannya.

Sebagai kesimpulan, aliran pemikiran klasik ini kiranya belum dapat menjawab realitas yang sesungguhnya dari problem kejahatan. Kajiannya terhadap masalah kriminalitas (berdasarkan postulat-postulat yang menjadi landasannya), seolah hanya terjebak pada gagasan-gagasan teoritik yang nyaris terlepas dari kenyataan kejahatan yang sebenarnya terjadi dalam kehidupan di tengahtengah masyarakat.

Merespon terhadap ketidakpuasan atas gagasan-gagasan yang diberikan oleh pemikiran klasik di atas, maka dalam perkembangannya ilmu kriminologi lahir suatu aliran pemikiran yang disebut dengan mazhab positivis. Aliran inilah yang pertamakali mendekati kategori "ilmiah" dalam upaya memahami problem kejahatan. Melalui studi ilmiah tentang kejahatan yang dipandang sebagai gejala sosial, para positivis mencoba menemukan hubungan sebab akibat (cause and effect relationship) dengan cara melakukan analisis terhadap perilaku kriminal yakni dengan mempelajari karakteristik fisik para pelanggar hukum (pelaku kejahatan). Mazhab ini berkeyakinan bahwa perilaku manusia ditentukan sebagian oleh faktor-faktor biologis, tetapi sebagian besar merupakan pencerminan karakteristik dunia sosiokultural di mana ia hidup?

'T. Sellin dalam "Culture' Conflict and Crime" sebagaimana dikutip Mardjono Reksodiputro.1994. Kriminologidan Sistem Peradilan Pidana. Jakarta: Penerbit Lembaga Kriminologi. Universitas Indonesia: HIm. 30. 
Dalam hubungan ini- secara lebih transparan, I:S. Susanto, juga menyatakan bahwa aliran pemikiran positif bertolak dari pandangan bahwa perilaku manusia ditentukan oleh faktor-faktor di luar kontrolnya, baik yang berupa faktor biologis maupun kultural. Ini berarti bahwa manusia bukan makhluk yang bebas untuk berbuat menuruti dorongan keinginannya dan inteligensinya, tetapi makhluk yang dibatasi dan ditentukan oleh perangkat biologis dan situasi kuituralnya. Manusia berubah dan berkembang bukan semata-mata karena inteligensinya akan tetapi melalui proses yang berjalan secara pelanpelan dari aspek biologisnya atau evolusi kultural. $^{8}$

Aliran positivis ini sangat menentang pendapat aliran klasik yang melihat manusia itu sebagai makhluk yang mempunyai kebebasan penuh dalam menentukan perilakunya (free will) dan selalu bersikap rasional hedonist. Karena pandangan free will itulah aliran klasik berpendapat bahwa satusatunya solusi yang terbaik bagi upaya penanggulangan terjadinya pelanggaran hukum pidana (kejahatan) ialah dengan meningkatkan efektivitas sanksi pidana yang diharapkan minimal akan memiliki deterence effect (penjeraan). Tidak periu dengan pendekatanpendekatan lain yang bersifat non penal. Perbuatan melanggar hukum pidana atau kejahatan dianggap sebagai kesengajaan pilihan si pelaku atas dasar kehendak bebas tadi.
Sebaliknya, dalam perspektif positivis karena kuatnya pengaruh determinisme biologis maupun determinisme sosio kultural dalam melihat perilaku/ perbuatan manusia, maka di dalam memandang problem kejahatan dan upaya untuk mengatasinya cenderung mengarah kepada usaha-usaha untuk menganalisis sebab-sebab perilaku kejahatan tersebut melalui studi ilmiah tentang ciri-ciri penjahat baik ditinjau dari aspek fisik/biologis, sosial maupun kulturalnya. ${ }^{9}$ Jadi, menànggulangi kejahatan tidaklah cukup dengan melalui penjatuhan pidana saja, melainkan harus dilakukan dengan menyelesaikan causa (sebabsebab)-nya terlebih dahulu yang menimbulkan kejahatan itu sendiri.

Secara komparatif, pemikiran positivis dapat dikatakan beberapa langkah lebih maju dibandingkan dengan pemikiran klasik. Studi tentang sebab-sebab kejahatan (Etiology Criminal) yang dapat berubah dan berbedabeda wujudnya di setiap tempat dan waktu, akan mendorong perkembangan kriminologi dan sekaligus mencegah terjadinya stagnasi ilmu.

Urgensi pengkajian terhadap faktor-faktor penyebab timbulnya kejahatan ini "juga direkomendasikan oleh Kongres PBB ke-7 tahun 1985 di Milan, Italia. Dalam dokumen $\mathrm{A}$ CONF 121/L/9 mengenai Crime Prevention in the Context of Development antara lain ditegaskan bahwa upaya penghapusan sebab-sebab dan kondisi yang menimbulkan

8I.S. Susanto. 1995. Kejahatan Korporasi. Semarang Badan Penerbit Universitas Diponegoro. HIm.7.

Sebagai perbandingan lihat Stephan Hurwitz. dalam Ny. Lamya Moeljatno. 1986. Kriminologi. Jakarta: PT Bina Aksara. HIm. 35-102. 
kejahatan harus merupakan strategi pencegahan kejahatan yang mendasar. Kebijakan-kebijakan mengenai pencegahan kejahatan harus mempertimbangkan sebabsebab struktural, termasuk sebab-sebab ketidakadilan yang bersifat sosio-ekonomis dimana kejahatan sering hanya merupakan suatu gejala/symptom. ${ }^{10}$

Dalam konfigurasi pemikiran positivis ini pula gagasan "embrional" tentang penanggulangan kejahatan dengan melalui upaya-upaya non penal mulai tumbuh dan mendapat perhatian. Apabila sebelumnya pemikiran klasik hanya melihat problem kejahatan dan upaya penanganannya melalui jalur penal semata di mana ini berarti lebih menitikberatkan pada sifat represif sesudah kejahatan terjadi, maka dalam jalur non penal titik beratnya adalah pada sifat preventif sebelum kejahatan terjadi.

Menurut Barda Nawawi Arief, mengingat upaya penanggulangan kejahatan lewat jalur non penal lebih bersifat tindakan pencegahan untuk terjadinya kejahatan, maka sasaran utamanya adalah penanganan faktor-faktor kondusif penyebab terjadinya kejahatan. Faktor-faktor kondusif itu antara lain berpusat pada masalah-masalah atau kondisi-kondisi sosial yang secara langsung maupun tidak langsung dapat menimbulkan atau bahkan menumbuhsuburkan kejahatan. ${ }^{11}$
Terlepas dari perkembangan yang konstruktif dari pemikiran positivis di atas (setidaknya dibandingkan dengan pemikiran klasik), bagaimanapun aliran ini masih belum mampu menguak secara lebih transparan berbagai proses sosial yang sebenarnya turut mendasari dan bahkan membentuk dunia realitas (c.q kejahatan). Hal demikian ini karena pemikiran positivis cenderung masih dalam taraf "eksplorasi" (penjajakan) terhadap apa yang disebut sebagai realitas sosial yang sesungguhnya tentang kejahatan. Indikatornya antara lain ialah masih terbelenggunya aliran ini dalam bingkai determinisme biologis dan sosio-kultural dalam menganalisis sebab kejahatan. Aspek-aspek penentu lainnya seperti kebijakan di bidang politik; kebijakan, dan di bidang hukum masih belum "terjamah" secara benar oleh mereka, sehingga secara keseluruhan pemikiran positivis masih belum dapat menunjang perkembangan kriminologi sebagai suatu ilmu yang memiliki peranan penting dalam mendukung operasionalisasi bidang-bidang ilmu yang lain seperti ilmu hukum pidana.

Dalam rangka menjawab kemungkinan terjadinya kejumudan serta kemandekan perkembangan ilmu kriminologi di atas, maka hadirnya new criminology, atau yang lebih populer dengan sebutan "kriminologi kritis" dapat dipandang sebagai alternatif yang

${ }^{10}$ Sevent United Nations Congress on the Prevention of Crime and Treatment of Offenders, Report, 1986, hal 94.

"Barda Nawawi Arief. 1996. Bunga Rampai Kebijakan Hukum Pidana. Bandung: Penerbit PT Citra Aditya Bakti. HIm. 49. 
sangat urgensif. Dalam aliran/pemikiran kritis ini, kriminalitas sebagai suatu social phenomenon ditatap secara lebih tajam dan mendalam, sesuai dengan namanya, analisis pemikiran ini dapat menghasilkan suatu solusi bagi problema kejahatan secara lebih jelas dan operasional (karena pandangannya tentang kejahatan yang integral komprehensif).

Dalam mazhab kritis ini, tidak lagi dianggap penting persoalan mengenai apakah manusia itu hakekatnya memiliki kebebasan dalam memilih perilakunya meliputi perilaku jahat/ kriminal (mazhab klasik) ataukah ia terikat pada faktor-faktor biologis, sosial dan kultural (seperti pandangan mazhab positivis). Pendekatan yang dipergunakan oleh mazhab ini dalam. upaya untuk memahami problem kejahatan lebih diarahkan pada kajian-kajian terhadap proses-proses sosial yang "dicurigai" sebagai "laten" dan potensial bagi terjadinya kejahatan. Secara global, pemikiran kritis menilai bahwa jumlah kejahatan yang terjadi maupun karakteristik para pelaku kejahatannya ditentukan terutama oleh bagaimana hukum pidana yang memandang suatu perbuatan sebagai kriminal itu dirumuskan dan bagaimana pula praktik pelaksanaannya (proses kriminalisasi dan proses law enforcement). Dalam konteks inilah pemikiran kritis. mulai "menggugat" dan sekaligus menggarisbawahi bahwa politik hukum tidak selamanya "lurus" dan "bebas" dari kepentingan non yuridis. Dalam kasus-kasus tertentu dari aliran ini kadang kala timbul suatu pandangan bahwa justru hukum dalam arti perundang-undangan pidana itu sendiri sebenarnya dapat menjadi faktor kriminogenik. Hal demikian ini karena undang-undang yang ada substansinya lebih berorientasi dan memihak pada kepentingan golongan tertentu penguasa dan pada saat yang sama mengabaikan atau bahkan menindas golongan lainnya. Jadi hukum dipergunakan sebagai alat. Hukum telah dikebiri. Hukum telah dipolitisir oleh mereka yang memiliki kekuasaan bagi kepentingan status quo mereka sendiri.

Dalam hubungan ini menarik untuk disimak contoh dari proses kriminalisasi terhadap perbuatan menggelandang dalam undang-undang penggelandangan di Inggris tahun 1849 yang ternyata sangat kriminogenik. Pada saat itu dunia usaha industri di Inggris sangat membutuhkan tenaga kerja (buruh) yang murah sesuai prinsip ekonomi yaitu: memperoleh keuntungan yang sebesarbesarnya pengorbanan yang sekecil-kecilnya. Tenaga buruh di Inggris saat itu banyak yang tidak berkeinginan bekerja pada usaha-usaha bidang industri, karena upah sebagai imbalan tenaga kerja yang diberikan tidak seimbang (murah). Mereka, lebih memilih melakukan kegiatan-kegiatan menguntungkan tanpa kerja keras seperti: mengemis/menggelandang, bertaruh, berjudi, dan lain sebagainya. Untuk mengatasi keadaan yang tidak menguntungkan dunia industri ini, para pengusàha mengusulkan untuk membuat Undangundang yang melarang mereka (buruh) bergelandangan dan perbuatan lain sejenisnya disertai sanksi pidana yang keras bagi mereka yang melanggarnya. Perundang-undangan ini mengakibatkan mempersempit ruang penghidupan, dan memaksa mereka bekerja di bidang industri, meskipun dengan upah yang murah. Yang menarik dari Ụndang-undang itu adalah bahwa pengertian gelandangan mencakup hal yang sangat luas. Selain mereka yang mengumpulkan sedekah, pemulung, juga mereka yang meninggalkan istri dan 
anak-anak, keluyuran, menginap di gudang, atau alam terbuka, dan orang-orang yang tidak mempunyai identitas. Mereka yang melakukan perbuatan-perbuatan ini, oleh undang-undang digolongkan sebagai penjahat..12

Berdasarkan deskripsi di atas, tentünya harus diambil sikap waspada dan cermat . dalam mendefinisikan serta memvonis: "apakah kejahatan itu" dan "siapakah penjahat itu". Sebab dari uraian di atas terlihat bagaimana kepentingan tertentu dari suatu golongan dalam masyarakat dapat mempengaruhi proses pembentukan aturan hukum pidana.

Dalam perkembangannya, studi kritis yang "menyoal" hubungan antara perundangundangan pidana dan masuknya kepentingankepentingan tertentu dalam suatu golongan masyarakat tersebut, tidak berhenti pada tataran proses kriminalisasi saja, melainkan telah meluas sampai pada proses peradilan pidana (law enforcement). Setidaknya ada dua hal yang mendorong perlunya ada pengkajian terhadap masalah proses peradilan pidana dikaitkan dengan kejahatan, yaitu: (1) hubungan antara proses peradilan pidana dengan pelanggar hukum. Menurut pengalaman, para pelanggar hukum terutama yang telah dijatuhi pidana dan sedang menjalani pidananya, walaupun di muka sidang pengadilan telah menyatakan menerima putusan hakim, namun jika kemudian ditanyakan kembali kepadanya mereka memberikan jawaban seolah-olah mereka tidak bersalah. (2) Bidang proses peradilan pidana ini perlu diperhatikan, karena hukum pidana tidak hanya diwujudkan dalam bentuk aturan perundang-undangan (law in the books) tetapi juga berbentuk suatu proses dalam praktik peradilan (criminal law in action). ${ }^{13}$ Dalam praktik peradilan itulah seringkali tejadi proses-proses penyimpangan/pemaksaan image tentang realitas kejahatan sebagaimana dikehendaki oleh perekayasa, yang pada gilirannya realitas sosial tentang kejahatan dan penjahat yang constructed tersebut seringkali mengaburkan terhadap apakah sesungguhnya yang dimaksud dengan kejahatan dan siapakah yang sebenarnya menjadi penjahat.

Dalam konteks indonesia kasus-kasus seperti tewasnya Udin wartawan harian Bernas Yogyakarta, tewasnya Marsinah, dan tewasnya Tjetje Tadjudin di Kepolisian Resor Bogor cukup representatif untuk dijadikan contoh bahwa dalam proses peradilan pidana ternyata apa yang dinamakan sebagai realitas sosial tentang kejahatan dan penjahat seringkali adalah hasil dari suatu konstruksi yang diarahkan, bukan cermin dari keadaan sesungguhnya.

Secara teoritik, latar belakang dari sikap "curiga"/selalu. mempertanyakan terhadap realitas sosial tentang kejahatan dan penjahat yang dikesankan oleh studi/pemikiran kritis di atas, dapat ditelusuri dan dijelaskan melalui perspektif teori konflik.

Menurut teori konflik sebagai salah satu model tentang' studi mengenai hubungan

\footnotetext{
${ }^{12}$ Chambliss William J. 1980. "A Sociological Analysis of The Law of Vagrancy". Dalam Satjipto Rahardjo. Hukum dan Masyarakat. Bandung: Penerbit Angkasa. Hlm. 39.

${ }^{13}$ Henkie Liklikuwata. Op Cit. Him. 10-11. Untuk dapat lebih memahami pentingnya studi kritis dalam proses bekerjanya hukum/proses peradilan pidana; antara lain dapat dibaca buku karangan Roeslan Saleh. 1983. Mengadili Sebagai Pergulatan Kemanusiaan. Jakarta: PT. Aksara Baru. HIm. 16-27.
} 
antara hukum dan masyarakat; hukum dipandang sebagai suatu mekanisme bagi yang memiliki kekuasaan politik untuk mencapai tujuan mereka. Hakekatnya hukum tidaklah selalu mencerminkan konsensus tentang nilai-nilai maupun persetujuan atas cara penyelesaian sengketa. Hukum dipandang cerminan kepentingan mereka yang memiliki kekuasaan untuk membuat dan menerapkan hukum, dengan mengabaikan terhadap kepentingan kelompok lain dalam masyarakat yang tidak memiliki kekuasaan tersebut. Sebagai akibatnya, maka undang-undang tidak hanya melayani kepentingan tertentu dai mereka yang berkuasa, tetapi juga untuk mempertahankan kekuasaan yang dimilikinya. Penjahat bagi mereka yang berkuasa adalah mereka yang memiliki tingkah laku yang bertentangan dengan kepentingan kekuasaan mereka. ${ }^{14}$.

Dalam perspektif teorikonflik di atas, mereka yang mempunyai kekuasaan yang lebih besar akan lebih mudah untuk menentukan dan mengendalikan perbuatan-perbuatan yang bertentangan dengan kepentingannya sebagai perilaku yang perlu diancam dengan sanksi pidana melalui rumusan undang-undang. Mereka juga lebih memiliki peluang (kekuasaan) untuk mempengaruhi pelaksanaan (penegakan) hukum sesuai yang diinginkannya (realitas sosial yang constructed).

Berdasarkan konstruksi teoritis di atas, maka tepat sekali analisis I.S. Susanto yang menyatakan bahwa: sehubungan dengan asumsi undang-undang adalah realitas sosial yang constructed, maka perlu dingat bahwa undang-undang hanyalah sekedar "janji-janji". Ini berarti bahwa undang-undang bisa berbeda dengan kenyataan yang sesungguhnya; sehingga dalam menganalisis hukum (undang-undang) kedua aspek tersebut harus diperhatikan. Artinya analisis kritis harus dilakukan baik terhadap proses pembuatan undang-undangnya maupun terhadap proses bekerjanya undang-undang itu sendiri dalam tahap law enforcement. Terhadap perundangundangan perlu dikaji tentang substansinya, yaitu seberapa jauh "cacat" yang dimilikinya, seperti kepentingan-kepentingan apa yang ada dibalik undang-undang, siapa atau kelompok masyarakat mana yang akan diuntungkan dari pengaturan undang-undang atau sebaliknya siapa yang akan dirugikan, apakah undangundang tersebut cukup adil, apakah sanksinya memadai dan manusiawi dan sebagainya. Mengenai penegakan hukum, paling tidak ada empat aspek yang dapat mempengaruhi kualitasnyā, yaitu di samping undangundangnya, juga pelanggar hukum, korban (masyarakat), dan aparat penegak hukumnya, di mana semuanya itu saling berhubungan serta mempengaruhi dan, berlangsung dalam wadah struktur politik, sosial, ekonomi dan budaya pada suatu situasi tertentu. ${ }^{15}$

Memperhatikan terhadap seluruh hal sebagaimana telah diuraikan di muka (khususnya sepanjang yang menyangkut tentang pemikiran kritis), dibanding dengan dua aliran/pemikiran

${ }^{14}$ Romli Atmasasmita. Op Cit. Him. 93.

'15.S. Susanto. "Pemahaman Kritis terhadap Realitas Sosial." Artikel dalam Majalah Masalah-Masalah Hukum. Fakultas Hukum UNDIP Semarang. Edisi No. 9-Tahun 1992. 
sebelumnya (klasik dan positivis) kiranya pemikiran kritis memiliki beberapa nilai tambah yang menjadikannya betul-betul sebagai alternatif inti bagi upaya pengembangan ilmu kriminologi. Beberapa manfaat sebagai nilai tambah tersebut antara lain ialah: pertama, dengan motivasi "penelanjangan dan penisbian realitas" tentang kejahatan ${ }^{16}$ pemikiran kritis akan dapat mempertajam penglihatan bahwa realitas sosial sebenarnya merupakan cermin dari konstruksi sosial. Hukum sebagai kenyataan tidak harus diyakini secara apriori sebagai suatu hasil internalisasi nilai-nilai sosial yang ada, melainkan lebih merupakan cermin kepentingan politik, sosial, budaya, hankam dan lain-lain. Dalam pandangan yang demikian, statistik kriminal misalnya bukanlah suatu gambaran dari kejahatan yang sesungguhnya akan tetapi lebih merupakan suatu fenomena yang dibuat/direkayasa untuk target-target tertentu. Kedua, dengan landasan motif "kurang hormat" dalam arti tidak pernah menerima sesuatu sebagaimana adanya, pemikiran kritis akan dapat membuka pemahaman kita mengenai proses-proses terbentuknya realitas karena sifatnya yang selalu mempertanyakan. Hal ini perlu dibedakan dengan mencurigai realitas. Sekalipun konsekuensi yang dapat ditimbulkannya bisa jadi sama yaitu tidak disukai oleh status quo (penguasa). Ketiga, dengan bermotif kosmopolitan dalam arti selalu terbuka terhadap kemungkinankemungkinan baru dalam rangka pemilihan alternatif yang terbaik, maka pemikiran kritis akan dapat merupakan suatu sarana untuk mengembangkan masyarakat yang demokratis dan transparan. Dengan sikap selalu mempertanyakan akan membuat perumus dan pemutus kebijakan sosial merasa dituntut lebih terbuka serta dialogis.

Nilai tambah seperti telah diidentifikasi di atas, setidaknya representatif untuk menjadi dasar bagi penarikan suatu kesimpulan bahwa pemikiran kritis memang sangat urgensif bagi upaya mengembangkan ilmu kriminologi. Proyeksi tentang "sosok" kriminologi di masa mendatang ialah sebuah ilmu yang mampu merekam dan merespon realitas sosial tentang kejahatan dalam artian yang sebenarnya maupun dalam artian yang constructed.

Betapapun juga eksistensi pemikiran kritis ini secara salah seringkali pula divonis sebagai pemikiran yang terlalu membela Marxisme. Karena latar belakang filosofisnya yang "dipayungi" oleh teori konflik di atas. Orientasi dan aplikasi teori konflik pada umumnya adalah bertalian erat dengan masalah politik dimana dalam konteks Marxisme maknanya ialah "perjuangan kelas" kaum proletar terhadap kemapanan kalangan penguasa yang pada umumnya terdiri dari kaum tiran/ borjuis/konglomerat dengan sejumlah kepentingan-kepentingannya. ${ }^{17}$

${ }^{16}$ lihat Peter L. Berger. 1974. Invitation to Sociology: A Humanistic Perspective.

${ }^{17} \mathrm{~J} . \mathrm{E}$. Sahetapy. Op Cit. HIm. 51 . Untuk memahami secara tepat dan proporsional tentang sejauhmana pemikiran tersebut identik ataukah tidak dengan Marxisme, setidaknya tulisan kriminolog I.S. Susanto dalam bukunya berjudul Kejahatan Korporasi kiranya dapat menjadi jembatan menuju problem solving. Lihat pula sebagai perbandingan Romli Atmasasmita. 1992. Teori dan Kapita Selekta Kriminologi. Bandung: PT Eresco.HIm. 42-51. 


\section{Gambaran Kriminologi dalam Konteks Indonesia}

Pada dasarnya pemikiran-pemikiran kriminologis yang berkembang dalam khasanah kepustakaan barat seperti telah diuraikan terdahulu juga merambah dalam cakrawala pikir para kriminolog Indonesia. Karena akar dan asal berkembangnya ilmu kriminologi memang di Barat khususnya di Amerika Serikat. Pemikiran kriminolog Indonesia setidaknya sebagaimana terlihat dalam karya-karya mereka dalam berbagai buku, sebagian besar adalah hasil dari konsumsi di barat. Sekalipun dalam halhal tertentu tetap ada analisis konteks Indonesia. Konsekuensinya berbagai aliran pemikiran kriminologi yang berkembang di barat (seperti klasik, positivis dan kritis) juga turut mewarnai kriminologi indonesia.

Namun demikian di antara ketiga aliran/ pemikiran tersebut apabila diamati dengan seksama, maka tampak bahwa kriminologi Indonesia ternyata masih di bawah "cengkeraman" kuat dari pengaruh aliran klasik dan positivis.

Untuk menggambarkan pengaruh aliran klasik misalnya, dalam berbagai tulisan terlihat dengan jelas keprihatinan terhadap meningkatnya kejahatan disertai dengan tuntutan diberikannya ancaman pidana yang lebih berat terhadap pelakunya, seperti maraknya kejahatan perkosaan atau kejahatan pembunuhan secara sadis beberapa waktu yang lalu. Dua kejahatan tersebut sangat gencar mendapatkan analisis dari kalangan ilmuwan dengan solusi akhir berupa usulan agar para pemerkosa atau pembunuh tersebut dihukum seberatberatnya. Bahkan, mantan Menteri Negara
Urusan Peranan Wanita pada masa Orde Baru, Ny. Mien Sugandhi pernah mengusulkan agar para pemerkosa dipidana mati saja.

Dalam perspektif kriminologis, adanya keyakinan bahwa ancaman pidana yang berat, praktik penegakan hukum yang tidak diskriminatif serta kepastian dalam penyelenggaraan sistem peradilan pidana secara keseluruhan akan dapat menanggulangi meningkatnya kriminalitas, adalah mencerminkan suatu pemikiran dari mazhab/aliran klasik yang melihat problem kejahatan hanya dengan kacamata yuridis (undang-undang hukum pidana) dan lebih mengutamakan perbaikan pada adminitration of justice sebagai upaya penangkalan kejahatan.

Selanjutnya pengaruh pemikiran positivis dalam kriminologi Indonesia setidaknya juga. diperlihatkan dari banyaknya karya-karya kriminolog Indonesia yang terlalu mengkiblatkan analisisnya pada tesis-tesis kriminolog positivis di barat. Dalam hubungan ini Mardjono Reksodiputro, mengemukakan hasil pengamatannya sebagai berikut: Pada dasarnya kriminologi di Indonesia masih bertitik tolak pada pengertian sebab kejahatan dalam arti sempit (dalam arti mazhab positivis). Buku kecil Bonger dan buku teks Sutherland dapat dikatakan mendasari banyak tulisan dan analisis kejahatan, meskipun tidak selaiu hal tersebut diungkapkan secara jelas. Pengaruh Bonger terutama terlihat dalam pengertian kejahatan yang digambarkan dengan dua lingkaran bertifik pusat satu (immoral and illegal dan illegal butnot immoral), dan keyakinan akan kuatnya pengaruh lingkungan (terutama yang berhubungan dengan faktor-faktor ekonomi). Dengan pendekatan differential association dari Sutherland, maka faktor pengaruh lingkungan ini diperluas pengertiannya dengan 
membawa aspek "proses belajar" dalam berkenalan dengan kejahatan. Pengaruh Sutherland (kriminolog Amerika) juga membuka pintu pemahaman bahwa aparat penegak hukum pidana (police, courts and correction) termasuk faktor lingkungan yang perlu diperhatikan dalam mempelajari sebab kejahatan. Perkembangan selanjutnya adalah masuknya pemikiran Sellin (Culture Conflict), Merton (Anomie), Cohen (Delinquent Subcutture), Cloward dan Ohlin (Illegitimate Opportunity Structure), Matza (Delinquency and Driff) dan lain-lain. Sebagaimana diketahui kesemuanya mereka ini dapat digolongkan dalam pemikir-pemikir mazhab positivis. ${ }^{1{ }^{\prime}}$

Gambaran selintas tentang masih kuatnya pengaruh pemikiran-pemikiran klasik dan positivis dalam kriminologi Indonesia di atas bukan berarti di Indonesia selama ini sama sekali tidak mengenal pemikiran kritis. Meskipun sedikit terlambat, menurut Mardjono, ${ }^{19}$ pada dasawarsa 1960-an' sebenarnya sudah mulai timbul kesadaran dalam kriminologi Indonesia bahwa masalah kejahatan atau sebab kejahatan tidak cukup hanya dipelajari melalui perbuatannya (mazhab klasik) dan juga tidak cukup melalui pelakunya (mazhab positivis) saja. Pada waktu itu di Indonesia sudah mulai dikenal bukubuku yang mencerminkan pemikiran kritis seperti Schur dalam Crimes Without Victims: Deviant Behavior and Public Policy (1965) dan buku Becker dalam Outsiders-Studies in Sociology of Deviance (1963). Dampak kedua buku ini tidak terlalu besar, atau pun pesan yang ingin disampaikan oleh kedua buku itu masih kurang dipahami. Baru kemudian dengan dikenalnya buku Quienney dalam The Social Reality of Crime (1970) dan buku Chambliss and Seidman dalam Law, Order and Power (1971), mulai timbul pemahaman tentang proses kriminalisasi (The Process of Defining Specific People and ACtion as Criminal), yang merupakan dasar pemikran/mazhab kritis. Tulisan-tulisan yang mempergunakan analisis kritis ini pada waktu itu memang belum banyak. Namun beberapa tulisan yang sudah dapat dikategorikan sebagai dalam kerangka pemikiran kritis antara lain adalah analisis yang menggugat luasnya masalah korupsi dan penyalahgunaan kekuasaan.

Dibandingkan dengan era 1960-an di atas, pada era sekarang ini (akhir1990-an dan 2000), perkembangan kriminologi Indonesia dapat dikatakan menunjukkan kemajuan yang menggembirakan. Artinya telah cukup banyak dewasa ini tulisan-tulisan yang mencerminkan analisis pemikiran kritis. Seperti sudah sering diseminarkannya masalah white collar crime (WCC), corporate crime, organized crime, dan lain-lain yang kemudian disusul dengan terbitnya beberapa karya tulis (buku) tentang masalah-masalah tersebut. Selain itu kejanggalan-kejanggalan yang terjadi dalam praktik peradilan di Indonesia akhir-akhir ini juga cukup tajam mendapat sorotan/analisis dari beberapa ahli yang kompeten. Sebagai contoh misalnya kasus putusan Mahkamah Agung yang menerima pengajuan PK

${ }^{18}$ Mardjono Reksodiputro. Op Cit. HIm. 32-33.

${ }^{18} / \mathrm{bid}$. HIm. 35. 
(Peninjauan Kembali) oleh Jaksa Penuntut Umum dalam kasus Muchtar Pakpahan, proses peradilan kasus Marsinah dan lain sebagainya.

Pendek kata dengan pendekatan melalui pemikiran kritis ini akan lebih dapat memperkaya wawasan dalam memahami problem kejạhatan. Sebab di dalamnya akan dilihat pula proses-proses yang berlangsung dalam keseluruhan gerak sistem peradilan pidana. Bahkan proses-proses pada saat kriminalisasi suatu perbuatan dalam undangundang hukum pidana yang menjadi landasan bekerjanya sistem peradilan pidana.

\section{Simpulan}

Sifat pemikiran kritis yang selalu "menggugat" hakekat atas realitas yang tampak tentang apa yang disebut sebagai kejahatan dan penjahat, menunjukkan adanya proses dinamisasi berpikir dalam mazhab ini yang terus berlangsung. Dalam konteks kriminologi, dinamika pemikiran kritis di atas sangat penting untuk memahami prosesproses yang menjadikan suatu perbuatan sebagai kejahatan dan proses-proses yang menjadikan seseorang mengalami ritual labeling sebagai penjahat. Sehingga dari pemahaman yang benar tentang prosesproses tersebut, selanjutnya dapat dijadikan dasar untuk menetapkan strategi kebijakan yang tepat dalam menanggulangi kejahatan.

Dalam konteks Indonesia, mengingat sifat serta fungsi dari pemikiran kritis sebagaimana ditegaskan dalam kesimpulan di atas, maka mazhab pemikiran kritis dipandang sangat urgen dalam upaya-upaya pengembangan ilmu kriminologi di masa mendatang. Hakekat pengembangan adalah suatu dinamika, sedangkan di antara ketiga pemikiran besar dalam kriminologi yang telah diuraikan di atas, tampaknya hanya mazhab kritis yang memenuhi kriteria sebutan sebagai pemikiran yang dinamis terutama karena sifatnya yang selalu "mempertanyakan" hakekat dari realitas yang tampak. $\square$.

\section{Daftar Pustaka}

Barda Nawawi Arief. 1996. Bunga Rampai Kebijakan Hukum Pidana. Bandung: Penerbit PT Citra Aditya Bakti.

Chambliss William J. 1980. A Sosiological Analysis of the Law of Vagrancy dalam Satjipto Rahardjo. Hukum dan Masyarakat Bandung: PenerbitAngkasa.

Henkie Liklikuwata. 1990. Sosiologi Hukum Pidana, Kejahatan dan Penjahat: Suatu Sketsa. Jakarta: Penerbit INDHILL CO.

I.S. Susanto. 1995.Kejahatan Korporasi. Semarang: Badan Penerbit UNDIP.

_., "Pemahaman Kritis Terhadap Realitas Sosial." Artikel dalam Majalah Masalah-Masalah Hukum. Fakultas Hukum UNDIP. Semarang. Edisi No. 9/ Th 1992.

1993. Kriminologi. Semarang: Bagian Penerbitan Fakultas Hukum UNDIP.

, "Lebih Jauh Tentang Studi Hukum Kritis." Wawancara termuat dalam Buletin Fokus. Edisi No. I/SPP/XV/ Desember 1996.

J.E. Sahetapy. 1992. Teori Kriminologi: Suatu Pengantar. Bandung: PT Citra Aditya - Bakti. 
Mardjono. Reksodiputro.1994. Kriminologi dan Sistem Peradilan Pidana. Jakarta: Penerbit Lembaga Kriminologi Universitas Indonesia.

Roeslan Saleh. 1983. Mengadili sebagai Pergulatan Kemanusiaan. Jakarta. Penerbit Aksara Baru.

Romli Atmasasmita. 1984. Bunga Rampai Kriminologi. Jakarta: Penerbit CV Rajawali.
-_- 1992.Teori dan Kapita Selekta 1 . Kriminologi. Bandung: PT. Eresco.

Seventh United Nations Congress on The Prevention of Crime and The Treatment of Offenders. Report. 1986.

Stephan Hurwitz dalam Ny. Lamya Moeljatno. 1986. Kriminologi. Jakarta: PT Bina Aksara. 